\title{
Trace element geochemistry and Sr-Nd characteristics of Mesoproterozoic mafic intrusive rocks from Rondônia, Brazil, SW Amazonian Craton: Petrogenetic and tectonic inferences
}

Instituto de Geociências, Universidade de São Paulo, Rua do Lago, 562. CEP 05508-080, Cidade Universitária, S. Paulo, Brazil.

*Corresponding author, girardi@usp.br

The Amazonian Craton comprises an Archean domain surrounded by four successively younger Proterozoic tectonic provinces. Within the Rio-Negro-Juruena province the Serra da Providência Intrusive Suite (1.60 and $1.53 \mathrm{Ga}$ ) consists of A-type rapakivi granites, charnockites and mangerites genetically associated with diabase dikes, gabbros and amphibolites. The original mafic melts were derived from a depleted mantle source $\left(\varepsilon_{N d(T)}+2.5\right.$ to +2.8 ; $\left.\varepsilon_{S r}(T)-12.1\right)$. Underplated mafic magma induced melting of a short-lived felsic crust, thus originating coeval felsic-mafic magmatism in a continental intraplate setting. The Colorado Complex, assigned to the Rondonian-San Ignacio province, comprises 1.35-1.36 Ga intrusive bimodal magmatism represented by monzonite gneisses associated with amphibolite, gabbro and metadiabase dikes intercalated with metasediments with detrital zircon that yield $U$ $\mathrm{Pb}$ ages of 1.35 to $1.42 \mathrm{Ga}$. Mafic samples display juvenile signatures $\left(\varepsilon_{N d(T)} 0.0\right.$ to +5.2 ; $\varepsilon_{S r}(T)-5.0$ to -30.7$)$ and are less contaminated than the Serra da Previdência and Nova Brasilândia ones. The generation of the basaltic magma is related to the subduction of an oceanic slab below the peridotite wedge (intraoceanic arc setting). Fluids and/or small melts from the slab impregnated the mantle. The Nova Brasilândia Sequence (Sunsas-Aguapeí province) comprises a metasedimentary sequence intruded by 1.10-1.02 Ga metadiabases, gabbros, meta-gabbros, and amphibolites associated with granitic plutons (bimodal magmatism). The original tholeiitic magmas, derived from a depleted source $\left(\varepsilon_{N d(T)}=+3.1\right.$ to +5.0$)$, in a proto-oceanic setting, underwent subsequent contamination by the host rocks, as indicated by the isotopic and trace element data.

\section{Introduction}

The tectonic scenario of the southwestern Amazonian Craton partly is assigned to three successively younger Proterozoic provinces: the Rio Negro-Juruena (RNJ; 1.80-1.55 Ga), Rondonian-San Ignacio (RSI; 1.55-1.30 Ga) and Sunsas-Aguapeí (SA; 1.25-0.97 Ga) (Figure 1), which result from several orogenic belts. These provinces

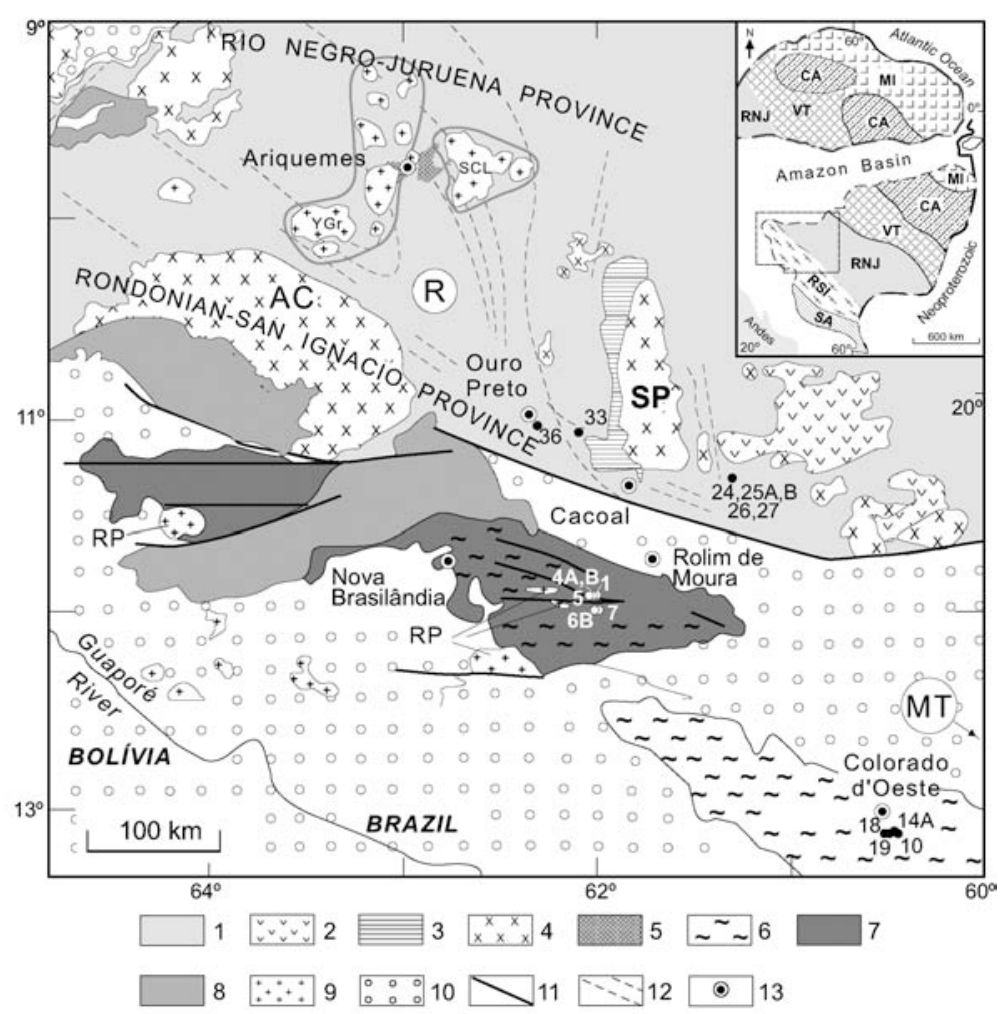

Figure 1 Geologic framework of the area, with location of the studied samples (adapted from Rizzotto et al., 2002). 1) Basement rocks partially reworked by Mesoproterozoic orogenies; 2) Roosevelt volcano-sedimentary sequence $(1.74 \mathrm{Ga})$; 3) Beneficente volcano-sedimentary sequence (1.69 Ga); 4) Intrusive granitoid suites ( $\mathrm{AC}=$ Alto Candeias, 1.34-1.35 Ga; $\mathrm{SP}=$ Serra da Providência, 1.60-1.53 Ga); 5) Rio Crespo Intrusive Suite (1.49 Ga); 6) Colorado Complex (1.36-1.35 Ga); 7) Nova Brasilândia Sequence; 8) Volcano-sedimentary cover related to the Sunsas-Aguapeí orogeny 9) Post-tectonic and anorogenic granitoid suites (SCL = Santa Clara, 1.08-1.07; RP = Rio Pardo, 1.05 Ga; YGr = Younger Granites of Rondônia, 0.99-0.97 Ga); 10) Phanerozoic; 11) Main structures; 12) Main shear zones. Keys: [R] State of Rondônia; [MT] State of Mato Grosso (located southeastward of the studied area). 13) Towns. 
can be distinguished, on the basis of lithology, structure, geochronology (U-Pb zircon ages) and isotopic signatures ( $\mathrm{Sr}-\mathrm{Nd}-\mathrm{Pb}$ ). According to Cordani and Teixeira (2007), the regional features of the SW part of the craton resulted from: a) continued Proterozoic soft-collision/accretion events (i.e., juvenile accretion and crustal reworking processes), b) development of thrust and fold belts, c) shear zones and rift basins accompanied by significant igneous activity represented by bimodal igneous suites (basalt-rhyolite, rapakivi, mangeritecharnockite-granite). The lower age limit of each province represents the cratonization stage of the country rocks, which is inferred from $\mathrm{U}-\mathrm{Pb}$ and $\mathrm{Pb}-\mathrm{Pb}$ radiometric ages of distinct rapakivi suites, mafic dikes and undeformed volcanic-sedimentary covers (e.g., Teixeira et al., 1989; Tassinari et al., 2000; Tassinari and Macambira, 2004). Alternative tectonic models based on precise SHRIMP and TIMS U-Pb ages in zircons, coupled with correlation of geologic units and regional scale structures have been presented (e.g. Santos et al., 2003) aiming at establishing subdivisions and tentative boundaries between the referred Proterozoic provinces. However these approaches do not preclude the classical model herein adopted, which is reinforced by the general conformity of the radiometric ages with the geological framework expected for a given province.

This work aims to advance our understanding on the nature of the sources and genetic models for mafic rocks associated with the Serra da Providência Intrusive Suite, Colorado Complex and Nova Brasilândia Sequence, which are tectonically and genetically related to the evolution of the RNJ, RSI, and SA provinces. For this purpose, we have combined geochemical and isotope data from the literature (Bettencourt et al., 1999a; Payolla et al., 2002; Rizzotto et al., 2001, 2002; Girardi et al., 2005; Teixeira et al., 2006; Rizzotto and Quadros, 2007) with new trace element data on mafic rocks to allow interpretations concerning the tectonic framework of the studied geological units. The integration of these data supports proposals for the tectonic settings of Serra da Providência Intrusive Suite (Bettencourt et al., 1999a and Payolla et al., 2002) and Nova Brasilândia Sequence ( Rizzoto et al., 2001 and Tohver, 2004), and to suggest a new model for the origin of the Colorado Complex.

\section{Geological framework}

The geotectonic scenario of the Amazonian Craton was recently reviewed by Cordani and Teixeira (2007). The geologic framework of the RNJ province (Figure 1) and the isotopic constraints of its granitoid rocks suggest the important role of juvenile magmatic arcs combined with minor reworking of crustal material formed in previous accretionary phases, in the interval 1.78-1.55 Ga (cf. Tassinari and Macambira, 2004). In addition, the geographic distribution of the ages throughout the province suggests that the accretionary wedges evolved from northeast to southwest (present position), adjacent to the cratonized Ventuari-Tapajós province, or cutting through its marginal zone within an Andean-type tectonic setting. A short time after regional cooling of the RNJ province at ca $1.55-1.50 \mathrm{Ga}$, the accretionary cycle was resumed, giving rise to the RSI province that occupies large parts of the Rondônia and Mato Grosso States (Brazil) and the Santa Cruz Department (Bolivia). The RSI province is characterized by granitoid rocks with radiometric ages between 1.50 and $1.30 \mathrm{Ga}$, which in contrast with the juvenile nature of most of the RNJ rocks, were formed in a collisional type environment. This hypothesis is supported by the large shear zones and granulite belts occurring along its northern border with the RNJ province. Regional cooling of the RSI province took place at 1.32-1.31 Ga (e.g., Teixeira et al. 2006).

The RNJ and RSI provinces behaved as a foreland for the collisional-type orogen $(1.25-1.00 \mathrm{Ga})$ that gave rise to the SA province, at the southwestern edge of the Amazonian Craton. The main geologic units of the SA province are low- to medium-grade metamorphic rocks and sedimentary basins originated in an extensional setting (e.g., Sunsas and Nova Brasilândia belts), subsequently subjected to transpression and crustal shortening as a result of the Sunsas orogen (e.g., Litherland et al., 1986; Sadowski and Bettencourt, 1996; Saes, 1999; Santos et al., 2000; Rizzotto et al., 2001).The Sunsas orogeny produced voluminous syn-tectonic plutonism, followed by post-tectonic (e.g., Santa Clara Intrusive Suite, 1.08-1.07 Ga, Rio Pardo Intrusive Suite, $1.05 \mathrm{Ga}$ ) and anorogenic intrusions (e.g., Geraldes et al., 2001). The anarogenic Younger Granites of Rondônia $(0.99-0.97 \mathrm{Ga})$ were emplaced within the RNJ and RSI provinces (e.g., Bettencourt et al. 1996, 1999a) (Figure 1). Moreover, sedimentary basins and mafic flows and sills related to extensional tectonics are also present in the SA province. After these plutonic and sedimentary events, the Amazonian Craton attained tectonic stability (Table 1).

\section{The Serra da Providência Intrusive Suite}

This is one of the several rapakivi suites (mangerite-charnockite-granite and associated mafic rocks) which occur in northern Rondônia State, RNJ province (Bettencourt et al., 1999a; Payolla et al., 2002; Santos, 2003). The rapakivi granites have subalkaline, slightly peraluminous composition, and exhibit A-type affinities (Bettencourt and Dall'Agnol 1995; Santos et al., 2003; Rizzotto et al., 1995). Diabases, metabasites, gabbroic and metagabbroic dikes, as well as amphibolites are also genetically related to this suite, as 
deduced from similar radiometric ages, tectonic setting, and field relationships (Payolla et al., 2002).

The Serra da Providência magmatism represents an intrusive event within the already cratonized RNJ crust (e.g., Tassinari et al., 2000), and was emplaced between 1.60 and $1.53 \mathrm{Ga}$, according to U$\mathrm{Pb}$ zircon geochronology (Payolla et al., 2002). This site is coeval with the Cachoeirinha orogen $(1.59-1.52 \mathrm{Ga})$ that developed farther southeast in the Mato Grosso State (Geraldes et al., 2004). Furthermore, the Serra da Providência rocks were variably affected by metamorphic events (Payolla et al., 2002), as were the host rocks, as a result of the tectonic reflex of the RSI and Sunsas orogenies (e.g., Santos et al., 2000; Teixeira et al., 2006) (Table 1).

The granitic and charnockitic rocks display $\varepsilon_{\mathrm{Nd}(\mathrm{T})}$ values from -0.6 to +2.0 , suggesting derivation from a mixture of predominantly juvenile sources with a slightly older crustal component (Bettencourt et al., 1999a; Payola et al., 2002). Additional ${ }^{40} \mathrm{Ar} /{ }^{39} \mathrm{Ar}$ geochronology of eleven selected mafic samples from this suite, including amphibolite, metagabbro, metadiabase and diabase, indicates a minimum estimate age for cooling of these rocks at $1556 \pm 6 \mathrm{Ma}$ (see Teixeira et al., 2006).

\section{The Colorado Complex}

The Colorado Complex in the northern Rondônia region (Figure 1) is the main magmatic event of the RSI province, and succeeded tectonic stability of the Cachoeirinha orogen (Table 1). The orogenic dynamics involved amalgamation of intra-oceanic arcs and accretionary prisms culminating with continental collision against the SW boundary of the RNJ province (e.g., Teixeira et al., 2006; Cordani and Teixeira, 2007).

The Colorado Complex consists of extension-related (passivemargin basin) amphibolite facies monzonitic gneiss genetically associated with amphibolite, gabbro and metadiabase intercalated with sillimanite schist, paragneiss (metaturbidites) and BIF. The metasedimentary rocks were intruded by mafic-ultramafic rocks and granitic injections (derived from melting of the pelites) that accompany strike-slip regional shearing and the development of mylonitic foliation, producing anastomosing portions and boudinage of the amphibolitic rocks, and accompanying the closure of the basin (Rizzotto et al., 2001; 2002). In addition, one high-grade metamorphism overprinted the Colorado Complex which is similarly recognized over large areas of the RSI province (e.g., Payolla et al. 2002, Cordani and Teixeira, 2007), such as over the Rio Crespo Intrusive Suite $(1.49 \mathrm{Ga}$ ) that occur ca. $700 \mathrm{~km}$ to the north in Rondônia (Figure 1).

Based on the comprehensive geochronologic and isotopic database of Rizzotto et al. (2002), Teixeira et al. (2006) and Rizzotto and Quadros (2007), the evolution of the Colorado Complex can be summarized as follows:

SHRIMP U/Pb detrital zircon ages of paragneisses range between $1.35-1.42 \mathrm{Ga}$. The youngest zircons estimate the maximum depositional age of these rocks, interpreted as originated in a passive margin basin (see above). The coeval monzonitic gneiss yields a $\mathrm{Rb} / \mathrm{Sr}$ whole rock isochron age of $1.36 \mathrm{Ga}$, and $\varepsilon_{\mathrm{Sr}}(\mathrm{T})$ and $\varepsilon_{\mathrm{Nd}}(\mathrm{T})$ values of +6.5 and +1.4 , respectively. One metagabbro yields a $\mathrm{U} / \mathrm{Pb}$ TIMS zircon crystallization age of $1352+4 /-3$ Ma. The granitic rocks have SHRIMP U/Pb zircon ages between 1346 and $1337 \mathrm{Ma}$ and show positive $\varepsilon_{\mathrm{Nd}(\mathrm{T})}$ values from +2.8 to +2.0 . Therefore, radiometric and isotopic data from felsic and mafic intrusives and intercalated metasedimentary rocks indicate their contemporaneity, and short crustal residence for the felsic suite protholith. Furthermore, the available ${ }^{40} \mathrm{Ar} /{ }^{39} \mathrm{Ar}$ analyses on muscovite from granitic veins and amphiboles from the amphibolites date from $1315 \pm 3$ to $1327 \pm 5 \mathrm{Ma}$, indicating the age of metamorphic cooling of the Colorado Complex.

\section{The Nova Brasilândia Sequence}

The Nova Brasilândia Sequence (Rizzotto et al., 2001, 2002) is assigned to the SA province (Figure 1). Tectonic evolution involved passive margin sedimentation with a maximum depositional age of $1.21 \mathrm{Ga}$, as supported by the SHRIMP U-Pb ages of the youngest group of detrital zircons (Santos, 2003). The observed strong deformation and high-grade metamorphism of the Nova Brasilândia rocks are contemporary with the onset of the Sunsas orogen (Litherland et al., 1986), and were accompanied by the emplacement of coeval felsic to mafic metaplutonic and plutonic rocks (sills and lenses of gabbro, metagabbro, amphibolite, metadiabase, and A-type granite) (Rizzotto et al., 2001). Nevertheless, an alternative tectonic view for the evolution of the Nova Brasilândia sequence advocates that throughout the SA province, transpressional suturing between Laurentia and Amazonia at ca. $1.10 \mathrm{Ga}$ (see Tohver et al., 2004, 2006) produced strong deformational and metamorphic features, along with emplacement of voluminous magmatic rocks with $\mathrm{U}-\mathrm{Pb}$ ages in the range of 1.08-1.07 Ga and 0.99-0.92 Ga (e.g., Litherland et al., 1986; Sadowski and Bettencourt, 1996).

According to Rizzotto et al. $(2001,2002)$, the magmatic evolution of the Nova Brasilândia sequence initiated with coeval gabbroic and monzogranitic magmas emplaced at $1.11 \mathrm{Ga}$, during an extensional phase of the oceanic lithosphere, giving rise to MORB-like magmas. This is in agreement with isotopic signatures of the most depleted mafic rocks $\left(\varepsilon_{\mathrm{Nd}(\mathrm{T})}=+3.1\right.$ to +5.0$)$. The felsic rocks give $\varepsilon_{\mathrm{Nd}(\mathrm{T})}$ value of -0.4 suggesting contamination from metasedimentary host-rocks $\left(\varepsilon_{\mathrm{Nd}}(\mathrm{T})=-3.1\right.$ to -4.3$)$. Injection of granitic melts at $1.10 \mathrm{Ga}\left(\varepsilon_{\mathrm{Nd}(\mathrm{T})}=-1.5\right)$ was contemporaneous with the transpressional regime and crustal shortening of the Nova Brasilândia sequence as a result of the Sunsas orogen, as evidenced by regional EW and WNW-ESE structures, and medium- to high-grade metamorphism. The extensional phase and final orogenic collapse of the Nova Brasilândia sequence was accompanied by emplacement of late- to post-tectonic granites dated at $1.05 \mathrm{Ga}\left(\varepsilon_{\mathrm{Nd}(\mathrm{T})}=+0.5\right)$.

Nova Brasilândia mafic rocks have ${ }^{40} \mathrm{Ar} /{ }^{39} \mathrm{Ar}$ plateau ages in the range of 1025 to $982-970 \mathrm{Ma}$ (Teixeira et al., 2006). This age span is comparable with U-Pb (titanite, monazite) ages and ${ }^{40} \mathrm{Ar} /{ }^{39} \mathrm{Ar}$ ages of the country rocks in the state of Rondônia, indicating regional cooling after tectonic stabilization at $1050 \mathrm{Ma}$ (Tohver et al., 2004). The youngest ${ }^{40} \mathrm{Ar} /{ }^{39} \mathrm{Ar}$ ages (982-970 Ma) may be related to shearing and mylonitization episodes at a regional scale (Rizzotto et al., 2001; Tohver et al., 2005). However, the latter age data may also reflect thermal influences from the emplacement of the Younger Granites of Rondônia that induced hydrothermal overprinting in their host rocks within the RSI and RNJ provinces (Bettencourt et al., 1999a, b).

\section{Analytical methods}

Bulk rock and trace element analyses were carried out at laboratories of the Departamento de Mineralogia e Geotectônica, Instituto de Geociências, Universidade de São Paulo, Brazil and reported in Table 2. Major element determinations were carried out at the X-ray fluorescence laboratory by wavelength dispersive X-ray spectrometery (Philips PW 2400) using fused glass discs according to the procedures described in Mori et al. (1999). Detection limits are on the order of 1-10 ppm. The precisions are better than $2 \%$. Trace element analyses were performed by Inductively Coupled Plasma-Mass Spectrometry (ICP-MS). Samples were dissolved in Parr bombs in a microwave furnace as described by Navarro et al. (2008). Accuracy, determined with respect to the reference standards BHVO-2 and BR, is $0.5-2 \%$. A comprehensive description of the $\mathrm{U}-\mathrm{Pb}$ and ${ }^{40} \mathrm{Ar} /{ }^{39} \mathrm{Ar}$ age determinations and $\mathrm{Nd}-\mathrm{Sr}$ isotopic geochemistry applied to the investigated units, including chemical routines and analytical uncertainties, are reported in Sato et al. (1995), Payolla et al. (2002) and Vasconcelos et al. (2002). 


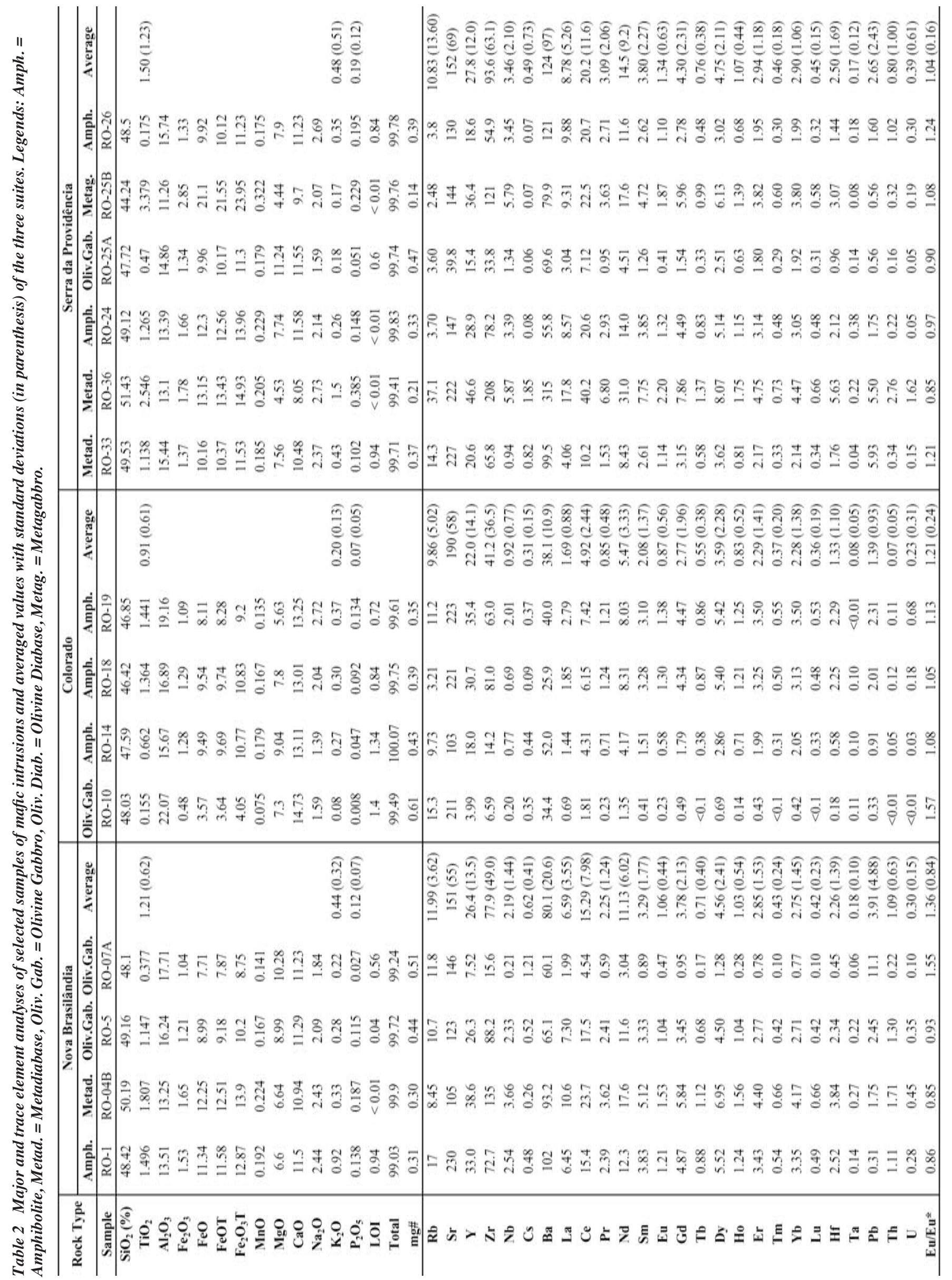




\section{Petrography and geochemistry of the mafic suites}

\section{Petrography}

The mafic rocks of the Serra da Providência Intrusive Suite include amphibolites, diabases, metadiabases, and gabbros. The amphibolites exhibit granoblastic texture and consist of andesine, hornblende, apatite, opaque minerals, and clinopyroxene. The granulite facies equivalents are characterized by labradorite and twopyroxene assemblages. The diabases display subophitic texture and are made up of clinopyroxene, plagioclase, brown olivine, apatite and opaques. Within the metadiabases plagioclase laths and pyroxenes are igneous relicts in a granoblastic assemblage formed mainly by plagioclase, hornblende and pyroxene. The metagabbros show granoblastic texture, and are mainly composed of labradorite and clinopyroxene with minor amounts of hornblende.

Intrusive mafic rocks of the Colorado Complex comprise amphibolites, gabbros and metadiabases. The Colorado amphibolites consist of hornblende, plagioclase (andesine-labradorite), apatite, titanite and opaque minerals. The texture is usually granoblastic. The gabbros are composed of plagioclase (labradorite), clinopyroxene, olivine, rare orthopyroxene and opaque minerals. In some of the amphibolites the texture is granoblastic polygonal, suggesting metamorphic re-equilibration. Metadiabases are made up of plagioclase, hornblende, clinopyroxene, orthopyroxene, quartz, apatite and opaque minerals. These rocks display two superimposed textures: the relict original subophitic one, and the granoblastic recrystallized assemblage, composed of plagioclase, hornblende and quartz.

The mafic rocks of the Nova Brasilândia Sequence comprise gabbros, metadiabases and amphibolites. The gabbros display ophitic texture and are made up of plagioclase (labradorite), clinopyroxene, olivine, biotite, and opaque minerals. Olivine is partially altered to
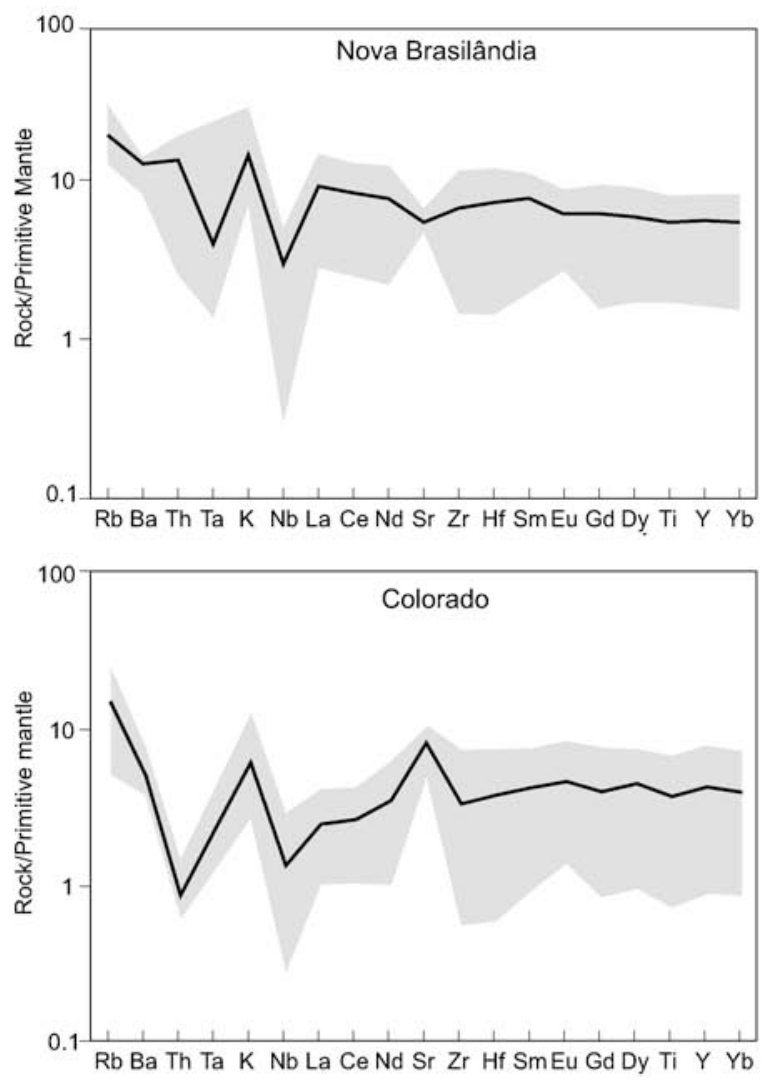

iddingsite, whereas hornblende and biotite replace clinopyroxene. Metadiabases are constituted by plagioclase, clinopyroxene, hornblende, apatite and opaque minerals. The original subophitic texture was partially recrystallized, as shown by small grains of newly formed clinopyroxene and hornblende that replace original clinopyroxenes. The amphibolites exhibit nematoblastic texture and consist of plagioclase (andesine-labradorite), hornblende in equilibrium with clinopyroxene, apatite, titanite, quartz and opaque minerals.

\section{Trace element geochemistry}

Girardi et al. (2005) previously reported major element geochemistry by XRF analyses of the mafic igneous and metamorphic rocks from the studied units. MPR (molecular proportional diagrams; see Pearce, 1968 and Beswick, 1982) and geochemical trends of $\mathrm{mg} \#\left[\left(\mathrm{mg}=\right.\right.$ atomic $\left.\mathrm{Mg} / \mathrm{Mg}+\mathrm{Fe}^{2}\right)$ ratio; assuming $\mathrm{Fe}_{2} \mathrm{O}_{3} / \mathrm{FeO}=$ $0.15]$ versus other elements display preservation of magmatic trends. The AFM diagram shows tholeiitic affinity. Decreasing $\mathrm{Al}_{2} \mathrm{O}_{3}, \mathrm{CaO}$, $\mathrm{Cr}$ and $\mathrm{Ni}$, increasing $\mathrm{Fe}_{2} \mathrm{O}_{3}, \mathrm{TiO}_{2}, \mathrm{P}_{2} \mathrm{O}_{5}, \mathrm{~K}_{2} \mathrm{O}, \mathrm{Na}_{2} \mathrm{O}, \mathrm{MnO}$ and

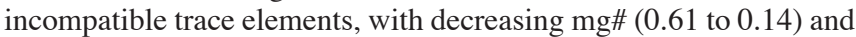
constant $\mathrm{Sr}$ content, indicate evolved tholeiitic magmas derived from parental melts through gabbro fractionation. Rizotto et al. (2001) came to similar conclusions by studying mafic rocks of the Nova Brasilândia Sequence.

In order to study the trace element geochemistry of the three investigated geologic units, fourteen selected samples were analyzed by ICP-MS (Table 2). Results show that the Serra da Providência and Nova Brasilândia display similar averaged values higher than those of the Colorado Complex (Figure 2). When compared with patterns and ratios presented by Sun and McDougall (1989) the REE from Serra da Providência and Nova Brasilândia samples are similar to E-MORB, whereas those from the Colorado ones tend to fit $\mathrm{N}$ MORB, as shown also by $\mathrm{La} / \mathrm{Yb}$ and $\mathrm{Ce} / \mathrm{Y}$ ratios. Some other ratios display similar behavior (e.g. $\mathrm{Zr} / \mathrm{Y}$ and $\mathrm{Ce} / \mathrm{Zr}$ in Serra da Providência, Ti/Y and Ce/Y in Nova Brasilândia, and Th/La in the Colorado
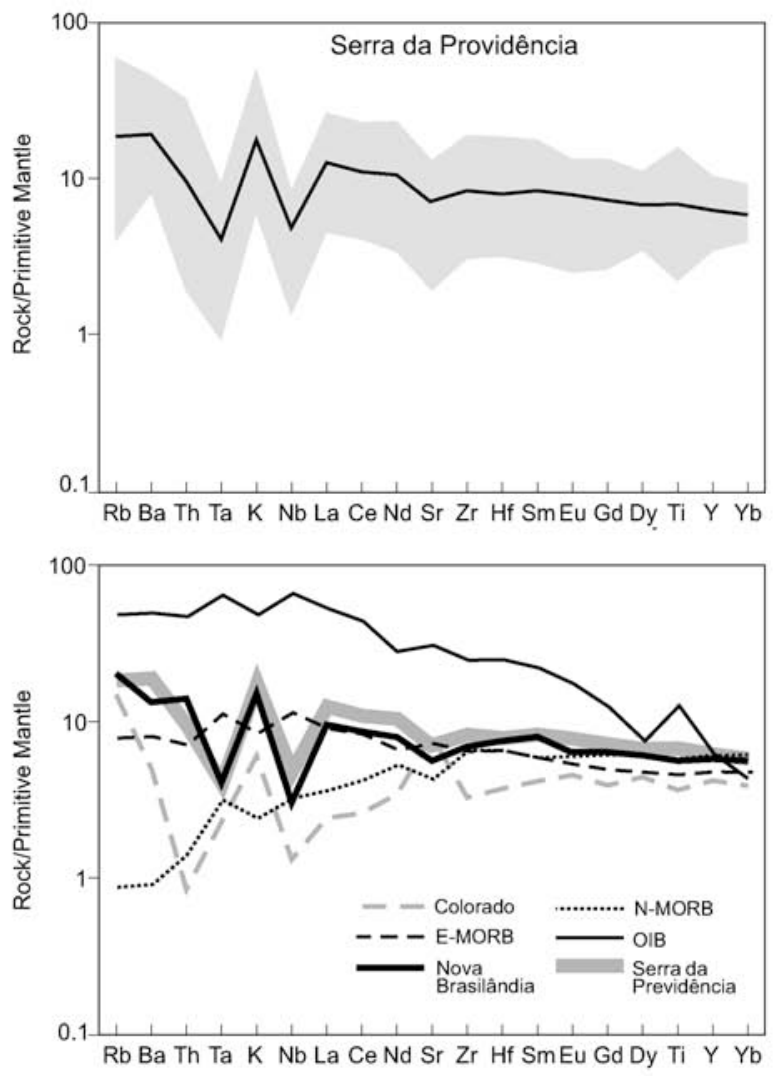

Figure 2 Primitive mantle normalized incompatible element patterns (averaged values and compositional fields) for selected mafic intrusives. OIB, N-MORB, E-MORB and primitive mantle from Sun and McDonough (1989). 
unit, cf. Table 3). Some samples exhibit positive anomalies of $\mathrm{Sr}$ and Eu likely related to plagioclase crystallization (Table 2 and Figure 2). However, there are strong differences between the three studied units and the E-MORB and N-MORB patterns and ratios due to the presence of pronounced positive spikes of $\mathrm{Rb}, \mathrm{Ba}, \mathrm{K}$, and remarkable negative peaks of $\mathrm{Nb}$ and $\mathrm{Ta}$ (Figure 2), which produce high LILE/HSFE and LREE/HSFE ratios (Table 3). These features characterize basalts typical of island arcs and intra-continental settings (e g. Brenan et al., 1994), and can be explained either by melts which experienced crustal contamination in the magma chamber or during ascent through the crust, or else originated from previously contaminated mantle, which underwent metasomatism or recycling of oceanic/continental crust (see discussion below). Table 3 displays also incompatible ratios of the intracratonic swarms from Uauá (Bellieni et al. 1995) and Salvador (Moraes Brito et al. 1989) (São Francisco Craton, Brazil), Goiás (Correa da Costa and Girardi, 2005) (Archean Block of Goiás, Brazil), and Uruguay (Bossi et al. 1993) (Rio de La Plata Craton) for comparison.

\section{Sr-Nd isotopes}

Sr-Nd isotopic data for 14 selected samples from the mafic units are listed in Table 4. Initial ${ }^{87} \mathrm{Sr} /{ }^{86} \mathrm{Sr}\left(\mathrm{Sr}_{\mathrm{i}}\right)$ ratios as well as $\varepsilon \mathrm{Sr}(\mathrm{T})$ and $\varepsilon_{\mathrm{Nd}(\mathrm{T})}$ values were calculated assuming ages of $1.55,1.35$ and $1.10 \mathrm{Ga}$ for the Serra da Providência, Colorado and Nova Brasilândia units, respectively. The $\varepsilon_{\mathrm{Sr}(\mathrm{T})}-\varepsilon_{\mathrm{Nd}(\mathrm{T})}$ plots (Figure 3) of $4 \mathrm{Col}-$ orado samples lie in the depleted quadrangle field $\left(\varepsilon_{\mathrm{Nd}(\mathrm{T})} 0\right.$ to +5.2 , $\varepsilon_{\mathrm{Sr}(\mathrm{T})}-30.7$ to -5$)$, showing the significant role of the DMM component in their genesis.

The Nova Brasilândia unit (4 samples of the unit) also display positive, but lower $\varepsilon_{\mathrm{Nd}(\mathrm{T})}$ values $(+0.1$ to +1.6$)$ and a larger $\varepsilon_{\mathrm{Sr}}(\mathrm{T})$ variation $(-2.4$ to +34.2$)$. The Serra da Providência Suite $(6$ samples $)$ forms two distinct compositional fields. The larger group lies close to "Bulk Earth" ( $\varepsilon_{\mathrm{Nd}(\mathrm{T})}-0.9$ to $+0.2, \varepsilon_{\mathrm{Sr}}(\mathrm{T})-3.3$ to 11.7$)$, which suggests a "chondritic" affinity, whereas the smaller is near to the Colorado field, and indicates a depleted composition $\left(\varepsilon_{\mathrm{Nd}(\mathrm{T})}+2.5\right.$ to $\left.+2.8, \varepsilon_{\mathrm{Sr}(\mathrm{T})}-12.1\right)$.

Table 3 Averages and ranges of incompatible trace element ratios for the selected samples of mafic intrusions, compared with OIB, N-MORB, E-MORB (Sun and McDonough (1989) and other dyke swarms: Uauá (Bellieni et al., 1995) and Salvador (Moraes Brito et al. 1989) (São Francisco Craton, Brazil), Goiás (Correa da Costa and Girardi, 2005) (Archean Block of Goiás, Brazil), and Uruguay (Bossi et al. 1993) (Rio de La Plata Craton).

\begin{tabular}{|c|c|c|c|c|c|c|c|c|c|c|c|}
\hline & $\begin{array}{c}\text { Nova } \\
\text { Brasilândia }\end{array}$ & Colorado & $\begin{array}{c}\text { Serra da } \\
\text { Providência }\end{array}$ & $\begin{array}{c}\text { N- } \\
\text { MORB }\end{array}$ & $\begin{array}{c}\text { E- } \\
\text { MORB }\end{array}$ & OIB & P.M & Uauá & Salvador & Goiás & Uruguay \\
\hline $\mathrm{Rb} / \mathrm{Sr}$ & 0.11 & 0.06 & 0.06 & 0.01 & 0.03 & 0.05 & 0.03 & 0.10 & 0.09 & 0.10 & 0.02 \\
\hline $\min -\max$ & $0.08-0.20$ & $0.01-0.09$ & $0.01-0.17$ & & & & & & & & \\
\hline $\mathrm{Zr} / \mathrm{Y}$ & 2.78 & 1.71 & 3.14 & 2.64 & 3.32 & 9.66 & 2.46 & 2 & 3.70 & 3.8 & 7.1 \\
\hline $\min -\max$ & $2.07-2.51$ & $0.79-2.63$ & $2.2-4.47$ & & & & & & & & \\
\hline $\mathrm{Ce} / \mathrm{Y}$ & 0.59 & 0.28 & 0.71 & 0.26 & 0.68 & 2.75 & 0.26 & 0.50 & 0.92 & 0.79 & 2.3 \\
\hline $\min -\max$ & $0.47-0.67$ & $0.20-0.45$ & $0.49-1.11$ & & & & & & & & \\
\hline $\mathrm{Ce} / \mathrm{Zr}$ & 0.22 & 0.19 & 0.23 & 0.10 & 0.21 & 0.29 & 0.1 & 0.25 & 0.23 & 0.20 & 0.22 \\
\hline $\min -\max$ & $0.18-0.29$ & $0.08-0.27$ & $0.15-0.38$ & & & & & & & & \\
\hline $\mathrm{La} / \mathrm{Yb}$ & 2.43 & 0.93 & 2.95 & 0.82 & 2.66 & 17.12 & 1.39 & 2.14 & 5.32 & 4 & 9.2 \\
\hline $\min -\max$ & $1.9-2.7$ & $0.6-1.6$ & $1.6-4.9$ & & & & & & & & \\
\hline $\mathrm{Ti} / \mathrm{Zr}$ & 106.63 & 164.57 & 107.37 & 103 & 82 & 61 & 90 & 135.3 & 93 & 78.7 & 68.3 \\
\hline $\min -\max$ & $77.98-145.1$ & $101-279.1$ & $73.2-167.8$ & & & & & & & & \\
\hline $\mathrm{La} / \mathrm{Nb}$ & 4.46 & 2.37 & 2.77 & 1.07 & 0.76 & 0.77 & 0.96 & 1.93 & 1.1 & 1.92 & 1.3 \\
\hline $\min -\max$ & $2.54-9.26$ & $1.39-3.54$ & $1.61-3.03$ & & & & & & & & \\
\hline $\mathrm{Ti} / \mathrm{Y}$ & 278.71 & 240.99 & 335.41 & 271 & 273 & 593 & 285 & 234 & 386 & 284 & 478 \\
\hline $\min -\max$ & $261.5-300.5$ & $220.5-266$ & 183.1-331.9 & & & & & & & & \\
\hline $\mathrm{Ba} / \mathrm{La}$ & 28.48 & 15.95 & 23.11 & 2.52 & 9.04 & 9.46 & 10.17 & 19.26 & 17.40 & 16.90 & 15.02 \\
\hline $\min -\max$ & $14.35-19.55$ & $8.81-30.19$ & $6.51-24.48$ & & & & & & & & \\
\hline $\mathrm{Th} / \mathrm{La}$ & 0.16 & 0.04 & 0.11 & 0.05 & 0.09 & 0.11 & 0.12 & & 0.24 & & \\
\hline $\min -\max$ & $0.11-0.18$ & $0.01-0.07$ & $0.03-0.16$ & & & & & & & & \\
\hline
\end{tabular}

Table 4 Measured $\mathrm{Rb}, \mathrm{Sr}, \mathrm{Sm}, \mathrm{Nd},{ }^{87} \mathrm{Sr} /{ }^{86} \mathrm{Sr},{ }^{143} \mathrm{Nd} /{ }^{144} \mathrm{Nd}$ values; calculated initial ${ }^{87} \mathrm{Sr} /{ }^{86} \mathrm{Sr}\left(\mathrm{Sr} r_{i}\right)$ ratios and $\varepsilon_{S r}(\mathrm{~T})$ and $\varepsilon_{N d(T)}$ values of selected samples from the mafic intrusions. Serra da Providência Intrusive Suite (1.55 Ga), Colorado Complex (1.35 Ga), Nova Brasilândia Sequence (1.10 Ga).

\begin{tabular}{|c|c|c|c|c|c|c|c|c|c|c|}
\hline Sample & $\begin{array}{l}\text { Age } \\
\text { (Ga) }\end{array}$ & $\begin{array}{c}\mathbf{R b} \\
(\mathrm{ppm})\end{array}$ & $\begin{array}{c}\mathrm{Sr} \\
(\mathrm{ppm})\end{array}$ & ${ }^{87} \mathrm{Sr} /{ }^{86} \mathrm{Sr}$ & $\mathrm{Sr}_{\mathrm{i}}$ & $\varepsilon_{\mathrm{Sr}(\mathrm{T})}$ & $\begin{array}{c}\mathrm{Sm} \\
(\mathrm{ppm})\end{array}$ & $\begin{array}{c}\text { Nd } \\
(\mathrm{ppm})\end{array}$ & ${ }^{143} \mathrm{Nd} /{ }^{144} \mathrm{Nd}$ & $\varepsilon_{\mathrm{Nd}(\mathrm{T})}$ \\
\hline RO-01 & 1.10 & 21.85 & 128.36 & $0.71080(6)$ & 0.70304 & -2.4 & 4.06 & 12.62 & $0.512688(12)$ & 1.3 \\
\hline RO-04 & 1.10 & 8.71 & 121.62 & $0.70693(3)$ & 0.70367 & 6.5 & 5.53 & 18.28 & $0.512621(15)$ & 1.6 \\
\hline RO-05 & 1.10 & 4.45 & 111.28 & $0.70745(4)$ & 0.70562 & 34.2 & 3.55 & 11.65 & $0.512604(14)$ & 1.1 \\
\hline RO-07 & 1.10 & 21.79 & 172.58 & $0.71063(6)$ & 0.70487 & 23.6 & 5.85 & 21.82 & $0.512394(9)$ & 0.1 \\
\hline RO-10 & 1.35 & 6.56 & 222.41 & $0.70337(1)$ & 0.70172 & -17.1 & 0.48 & 1.51 & $0.512747(29)$ & 2.7 \\
\hline RO-14 & 1.35 & 7.54 & 105.86 & $0.70529(7)$ & 0.70130 & -23.1 & 1.67 & 4.71 & $0.512798(14)$ & 0.0 \\
\hline RO-18 & 1.35 & 2.70 & 214.74 & $0.70327(3)$ & 0.70257 & -5.0 & 3.17 & 7.78 & $0.513287(13)$ & 4.1 \\
\hline RO-19 & 1.35 & 20.26 & 262.35 & $0.70509(6)$ & 0.70076 & -30.7 & 3.39 & 8.41 & $0.513321(8)$ & 5.2 \\
\hline RO-24 & 1.55 & 4.23 & 159.41 & $0.70522(6)$ & 0.70373 & 11.7 & 3.39 & 8.41 & $0.512367(14)$ & 0.2 \\
\hline RO- $25 \mathrm{~A}$ & 1.55 & 4.29 & 44.51 & $0.70872(1)$ & 0.70332 & -2.4 & 3.39 & 8.41 & $0.512413(13)$ & -0.6 \\
\hline RO-25B & 1.55 & 1.57 & 175.03 & $0.70379(2)$ & 0.70329 & 7.5 & 3.39 & 8.41 & $0.512359(11)$ & -0.5 \\
\hline RO-26 & 1.55 & 4.34 & 294.61 & $0.70340(3)$ & 0.70258 & -3.3 & 3.39 & 8.41 & $0.512002(13)$ & -0.9 \\
\hline RO-33 & 1.55 & 12.43 & 227.72 & $0.70535(6)$ & 0.70229 & -12.1 & 2.41 & 7.66 & $0.512699(10)$ & 2.5 \\
\hline RO-36 & 1.55 & 42.76 & 263.65 & $0.71229(8)$ & 0.70320 & -12.1 & 8.05 & 30.74 & $0.512393(14)$ & 2.8 \\
\hline
\end{tabular}




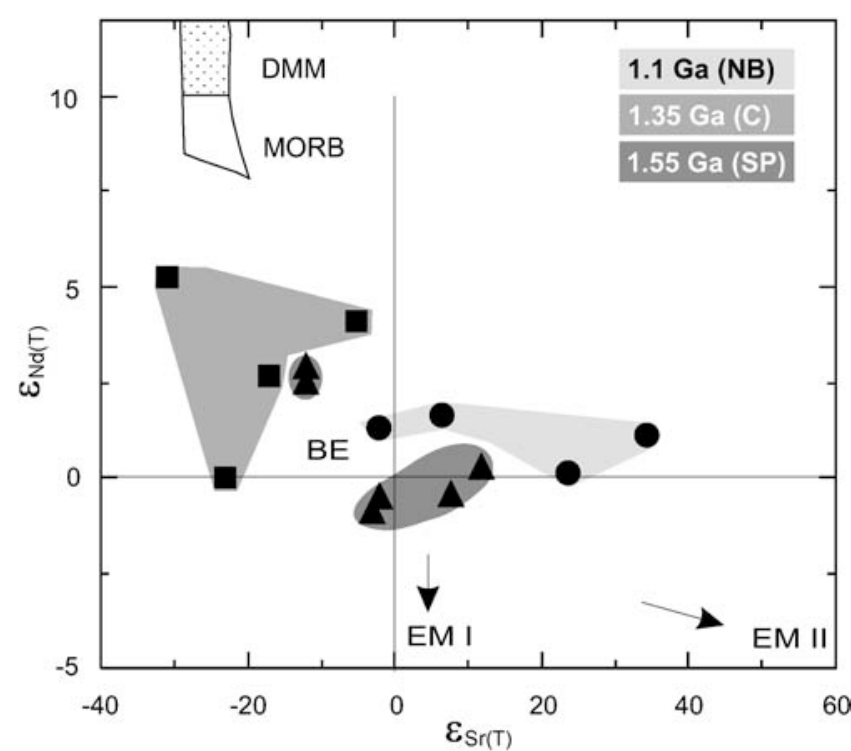

Figure $3 \varepsilon_{S r(T)}$ vs. $\varepsilon_{N d(T)}$ diagram for samples of the mafic intrusions. Key symbols: Serra da Providência Intrusive Suite - SP $(1.55 \mathrm{Ga})$ : triangle; Colorado Complex $-C(1.35 \mathrm{Ga})$ : square. Nova Brasilândia Sequence - NB (1.10 Ga): circle. MORB, EMI, EMII after Zindler and Hart (1986) and DMM after Rollinson (1993).

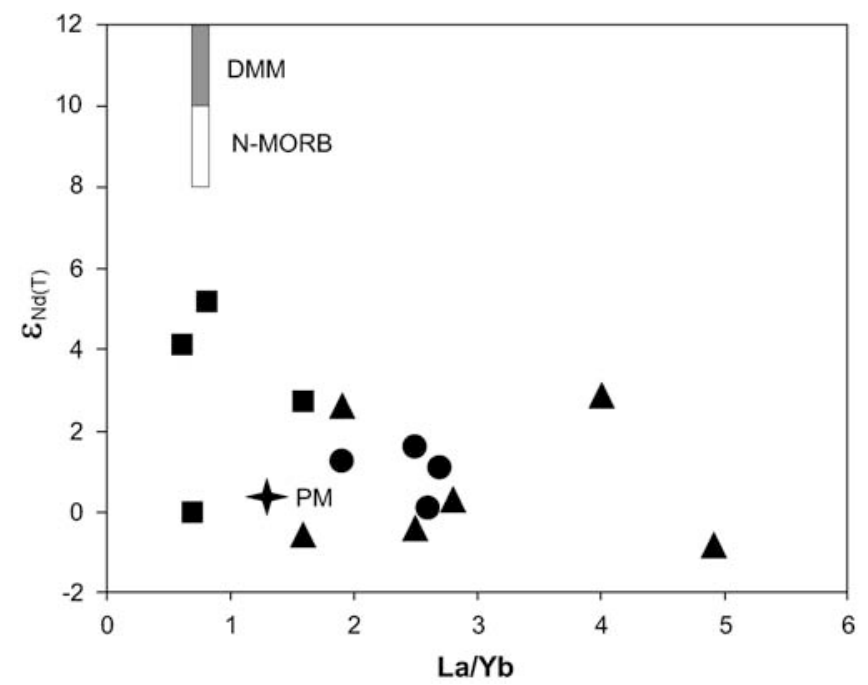

Figure $4 \varepsilon_{N d(T)} v s . \mathrm{La} / \mathrm{Yb}$ diagram for selected samples of the mafic intrusions. Symbols, as in Figure 3. PM = primitive mantle, after Sun and McDonough (1989).

\section{Petrogenetic and tectonic implications}

The $\varepsilon_{\mathrm{Nd}(\mathrm{T})}$ vs. La/Yb diagram (Figure 4) displays the relationship of trace element and isotopic composition of the investigated units. The Colorado samples have higher $\varepsilon_{\mathrm{Nd}}(\mathrm{T})$ and lower $\mathrm{La} / \mathrm{Yb}$ ratios. Only one sample is slightly displaced to the right of primitive mantle values, thus indicating that the Colorado mafic rocks were the least affected by crustal contamination. The Serra da Providência and Nova Brasilândia units display higher $\mathrm{La} / \mathrm{Yb}$ ratios, and consequently a larger degree of crustal contamination, as also shown by their respective spidergrams (Figure 2).

One difficult task concerning the petrogenesis of mafic rocks is the determination of whether the contamination occurred within the mantle source, or through assimilation of country-rocks, either in the magma chamber or during the ascent of the magma. In this respect the distinctive correlation between isotopic parameters and element concentration or ratios can be a useful tool.

The Serra da Providência samples do not display either negative correlations between $\varepsilon_{\mathrm{Nd}}(\mathrm{T})$ and $\mathrm{La} / \mathrm{Yb}$ (Figure 4) or positive trends

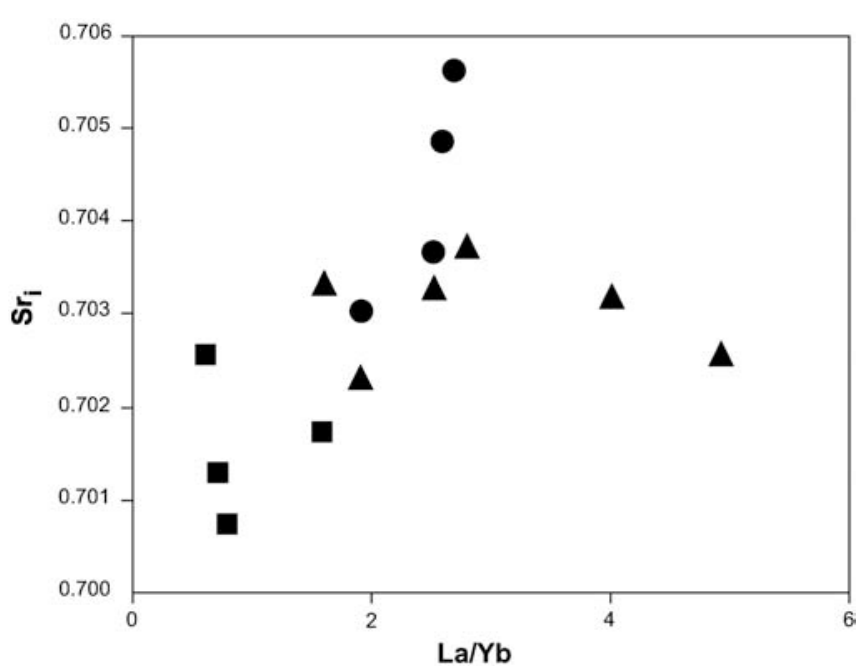

Figure $5 S_{i}$ vs. La/Yb diagram for selected samples of the mafic intrusions. Symbols as in Figure 3.

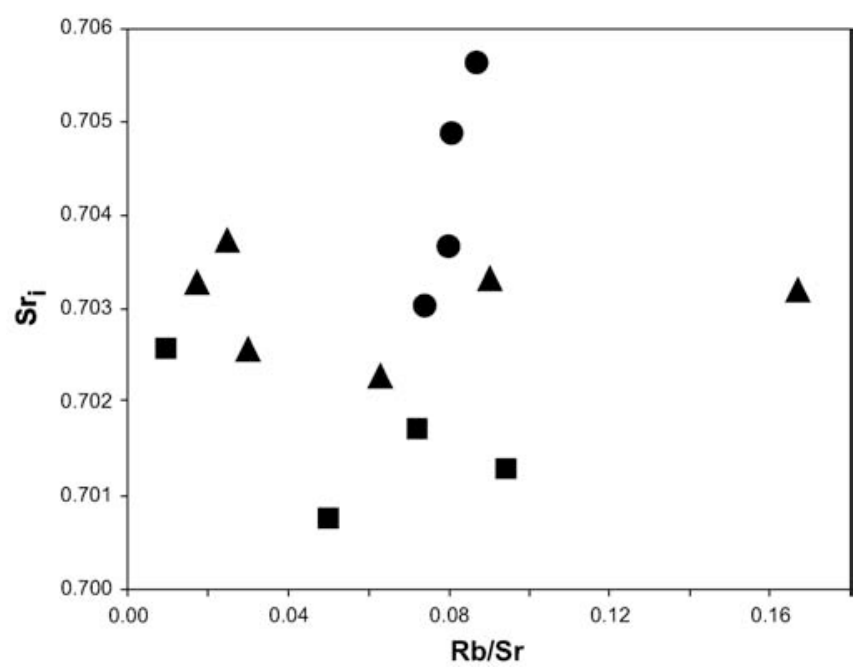

Figure $6 \mathrm{Sr}_{i} v \mathrm{vs} . \mathrm{Rb} / \mathrm{Sr}$ diagram for selected samples of the mafic intrusions. Symbols as in Figure 3.

between $\mathrm{Sr}_{\mathrm{i}}$ and $\mathrm{La} / \mathrm{Yb}$ (Figure 5), and $\mathrm{Sr}_{\mathrm{i}}$ and $\mathrm{Rb} / \mathrm{Sr}$ (Figure 6), as expected during crustal assimilation of older country rocks. However, $\mathrm{Rb} / \mathrm{Sr}$ variation is quite large (Table 3, Figure 6), in contrast with the virtually constant and low Sri values (Table 4). This likely means that $\mathrm{Rb}$ enrichment did not affect Sri values, thus characterizing a decoupling between isotopic parameters, LILE and LREE concentrations. According to Bettencourt et al. (1999a) and Payolla et al. (2002), the Serra da Providência felsic and mafic suites, resulting from bimodal magmatism, are coeval, and their $\varepsilon_{\mathrm{Nd}(\mathrm{T})}$ values range from -0.6 to +2.0 , and from -0.9 to +2.8 respectively (Table 4 ). According to Frost (2002), such an isotopic overlap for these mafic and felsic rocks would result from fractional crystallization of mantle-derived magmas.

Alternatively, Haapala et al. (2005) propose that mantle-derived mafic magmas reaching the crust-mantle boundary (underplating) melt part of the lower crust, producing granitic magma. Intrusions of these mafic and felsic melts into higher crustal levels give rise to bimodal magmatism. Bettencourt et al. (1999a) and Payolla et al. (2002) advocate the last model for the origin of the Serra da Providência Intrusive Suite, which would favor a predominance of granitic rocks, as shown by field mapping. The samples lying in the depleted quadrangle $\left(\varepsilon_{\mathrm{Nd}(\mathrm{T})}+2.5\right.$ and +2.8 , Table 4 , Figure 3$)$ would represent the least contaminated parental mafic magma. Contamination by acidic to intermediate melts would probably be the main cause for the pronounced $\mathrm{Ba}, \mathrm{K}, \mathrm{Rb}, \mathrm{La}$ and $\mathrm{Ce}$ positive anomalies of the mafic 
rocks. Similar $\varepsilon_{\mathrm{Nd}(\mathrm{T})}$ ranges of the most contaminated basaltic melts and the granite-charnockite suite suggest a short residence of the melted pre-existent crust, which would account for the decoupling of LREE, LILE and Sri in the basic rocks. As such, the proposed model favors a continental intraplate setting for the Serra da Providência Intrusive Suite.

Coeval mafic and felsic rocks (ca. $1.35 \mathrm{Ga}$ ) of the Colorado Complex display similar positive $\varepsilon_{\mathrm{Nd}(\mathrm{T})}$ values, ranging from zero to +5.2 (Table 4) and from +1.4 to +6.5 (Rizzoto et al., 2002; Teixeira et al., 2006) respectively, which is compatible with derivation in an intra-oceanic environment. Contamination of mafic rocks, although present, is significantly lesser than that observed in the Serra da Providência and Nova Brasilândia samples. These geochemical and isotopic parameters, as well as the contemporaneous sedimentation represented by turbidites with $\mathrm{U} / \mathrm{Pb}$ zircon detrital ages ranging from approximately 1.35 to $1.42 \mathrm{Ga}$ (Rizzotto and Quadros, 2007), suggest that generation of the Colorado basaltic magma took place after oceanic crust rupture and subsequent rifting. In our view this was followed by oceanic slab subduction below the peridotite wedge (island arc setting), in partial agreement with the original ideas of Rizzotto and Quadros (2007). In this scenario fluids and/or small melt fractions generated from the slab induced metasomatism in the overlying mantle. The observed LILE and LREE enrichment are attributed to overlying sediments (e.g., Weaver, 1991), whereas retention by rutile in the slab eclogites may have produced the observed negative $\mathrm{Nb}-\mathrm{Ta}$ anomalies (e.g. Cordery et al., 1997; Takahashi et al., 1998; Ayers, 1998; Rivalenti et al., 1998; Leitch and Davis, 2001). Small amounts of rutile $(\sim 2 \%)$ would be enough to prevent HSFE enrichment in the mantle wedge (Brenan et al., 1994).

The felsic plutonic and coeval mafic rocks of the Nova Brasilândia Sequence intruded metapelitic gneisses and calc-silicate rocks at 1.02-1.10 Ga (Rizzotto et al., 2001; Teixeira et al., 2006). The metasedimentary host rocks display $\varepsilon_{\mathrm{Nd}(\mathrm{T})}$ values ranging from -3.8 to -4.3 (Rizzoto, 1999). The $\varepsilon_{\mathrm{Nd}}(\mathrm{T})$ data are slightly positive ( +0.1 to +0.6 , Table 4, Figure 3$)$, but Rizzoto et al. (2001) report substantial higher values $(+3.1$ to +5.0$)$ for other Nova Brasilândia mafic rocks. This variation and the large range in $\varepsilon_{\mathrm{Sr}}(\mathrm{T})$ values $(-2.4$ to 34.2 , Table 4) indicate significant contamination, which is also supported by trace element data. Sri values correlate positively with $\mathrm{La} / \mathrm{Yb}$ (Figure 5) and with $\mathrm{Rb} / \mathrm{Sr}$ ratios (Figure 6), whereas the $\mu \mathrm{Nd}$ vs. La/Yb diagram suggests a negative correlation (Figure 4), thus indicating that the mafic melts underwent crustal contamination by older country rocks.

Summarizing, the available isotopic and geochemical data for the Nova Brasilândia Sequence indicate that the original mafic suite is consistent with an oceanic setting with subsequent crustal contamination. These data are compatible with the intrusion of basaltic magmas into metasedimentary rocks including deep-sea and continental sediments during the evolution of a narrow proto-ocean; and are consistent with both models of Rizzoto et al. (2001) and Tohver et al. (2004).

\section{Acknowledgements}

This research was supported by FAPESP (proc. 07/58762-2) and CNPq. Suggestions and criticism made by the reviewers P. CominChiaramonti and E. P. de Oliveira benefited the article. Special thanks are due to J. D. Kirk for the linguistic improvements.

\section{References}

Ayers, J., 1998, Trace element modeling of aqueous fluid-peridotite interaction in the mantle wedge of subduction zones: Contributions to Mineralogy and Petrology, v. 132 , pp. $390-404$.

Beswick, A.E., 1982, Some geochemical aspects of alteration and genetic relations in komatiitic suites. In: Arndt, N.T., and Nesbitt, E.G., eds, Komatiites: London, George Allen and Unwin, pp. 283-308

Bellieni, G., Piccirillo, E. M., Petrini, R., Girardi, V. A. V., Menezes Leal, A. B., Teixeira, W., Bastos Leal, L. R., De Min, A., Comin Chiaramonti, P., and Tanner de Oliveira,
M. A. F., 1995. Petrological and Sr-Nd evidence bearing on Early Proterozoic magmatic events of the subcontinental mantle: Sao Francisco Craton (Uauá, NE-Brazil). Contribution to Mineralogy and Petrology, v. 122, p. 252-261.

Bettencourt, J.S., Onstott, T.C., De Jesus, T., and Teixeira, W., 1996, Tectonic implications of ${ }^{40} \mathrm{Ar} /{ }^{39} \mathrm{Ar}$ ages on country rocks from the central sector of the Rio Negro-Juruena Province, southwest Amazonian Craton: International Geology Review, v. 38, pp. 42-56.

Bettencourt, J.S., and Dall'Agnoll, R., eds, 1995, The Rondonian Tin-bearing anorogenic granites and associated mineralization: Symposium on Rapakivi Granites and Related Rocks, IGCP Project 315, Belém, Brazil. Excursion guide, The Rapakivi Granites of the Rondonia Tin Province and Associated Mineralization, $48 \mathrm{p}$.

Bettencourt, J.S., Tosdal, R.M., Leite Junior, W.B., and Payolla, B.L., 1999a, Mesoproterozoic rapakivi granites of Rondonia Tin Province, south-western border of the Amazonian Craton, Brazil - I. Reconnaissance U-Pb geochronology and regional implications: Precambrian Research, v. 95, pp. 41-67.

Bettencourt, J.S., Payolla, B.L., Leite Junior, W. B., Tosdal, R.M., and Spiro, B., 1999b, Mesoproterozoic rapakivi granites of Rondonia Tin Province, southwestern border of Amazonian craton, Brazil: Reconnaissance $\mathrm{Nd}, \mathrm{Sr}, \mathrm{O}, \mathrm{Pb}$ isotopic geochemistry and regional implications. In: Barbarin, B., ed, Fourth Hutton Symposium: Clermont Ferrand, France. Abstracts, Documents du BRGM 290, 132.

Bossi, J., Campal, N., Civetta, L., Demarchi, G., Girardi, V. A. V., Mazzucchelli, M., Negrini, L., Rivalenti, G., Fragoso Cesar, A. R. S., Sinigoi, S., Teixeira, W., Piccirillo, E. M., and Molesini, M., 1993. Early Proterozoic dike swarms from western Uruguay: geochemistry, $\mathrm{Sr}-\mathrm{Nd}$ isotopes and petrogenesis. Chemical Geology, v. 106 , p. 263-277.

Brenan, J.M., Shaw, H.F., Phinney, D.L., Ryerson, F.J., 1994, Rutile-aqueous partitioning of $\mathrm{Nb}, \mathrm{Ta}, \mathrm{Hf}, \mathrm{Zr}, \mathrm{U}$ and $\mathrm{Th}$ : implications for high field strength element depletions in island-arc basalts: Earth and Planetary Science Letters, v. 128, pp. 327-339.

Cordani, U.G., Teixeira, W., 2007, Proterozoic Accretionary belts in the Amazonian Craton. In: Hatcher Jr., R.D., Carlson, M.P., McBride, J.H., and Martinez Catalán, J.R., org, The 4D Framework of Continental Crust: GSA Memoir, Boulder, Colorado. Geological Society of America Book Editors, 2007, v. 200, pp. 297-320.

Cordery, M.C., Davies, J.F., Campbell, I.H., 1997, Genesis of flood basalts from eclogite-bearing mantle plumes: Journal of Geophysical Research, v. 102, pp. 20179-20198.

Corrêa da Costa, P. C., and Girardi, V. A. V., 2005. Petrology, geochemistry and Sr-Nd isotopes of the Paleoproterozoic dikes from the Goiás - Crixás Archean Block, Goiás State, Brazil. Revista Brasileira de Geociências, V.35(1):135-150.

Frost, C.D., Frost, B.R., Charmberlain, K.R., 2002, The relationship between A-type granites and residual magmas from anorthosites: evidence from the northern Sherman batholith, Laramie Mountains, Wyoming, USA: Precambrian Research, v. 116 , pp. 45-71.

Geraldes, M.C., Teixeira, W., and Heilbron, M., 2004, Lithospheric versus asthenospheric source of the SW Amazonian craton A-type granites: the role of the Paleoand Mesoproterozoic accretionary belts for their coeval continental suite: Episodes, v. 27(3), pp. 185-189.

Geraldes, M.C., Van Schmus, W.R., Condie, K.C., Bell, S., Teixeira, W.; Babinski, M., 2001. Proterozoic geologic evolution of the SW part of the Amazonian Craton in Mato Grosso state, Brazil: Precambrian Research 111: 91-128.

Girardi, V.A.V., Teixeira, W., Bettencourt, J.S., Corrêa da Costa, P.C., and Sato, K., 2005, Características isotópicas (Nd, Sr) e geoquímicas de rochas intrusivas máficas mesoproterozóicas do Estado da Rondônia, SW do Craton Amazônico: Anais do X Congresso Brasileiro de Geoquímica e II Simpósio de Geoquímica de Países do Mercosul: Porto de Galinhas, Pernambuco. Resumos Expandidos, CD-ROM, 4 p.

Haapala, I., Rämo, O.T., Frindt, S., 2005, Comparison of Proterozioc and Phanerozoic rift-related basaltic-granitic magmatism. Granitic Systems - Ilmari Haapala Volume: Elsevier, Finland, ed, Rämö, O.T.: Lithos, v. 80, pp. 1-32.

Leitch, A.M., and Davis, G.F., 2001, Mantle plumes and flood basalts: enhanced melting from plume ascent and an eclogite component: Journal of Geophysical Research, v. 106, pp. 2047-2059.

Litherland, M., Annels, R.N., Appleton, J.D., Berrange, J.P., Boomfield, K., Darbyshire, D.P.F., Fletcher, C.J.N., Hawkins, M.P., Klinck, B.A., Mitchell, W.I., O'Connor, E.A., Pitfield, P.E.J., Power, G., and Webb, B.C., 1986, The geology and mineral resources of the Bolivian Precambrian Shield: Overseas Memoir, British Geological Survey, v. 9, 153 p.

Moraes Brito, C., Bellieni, G., Comin-Chiaramonti, P., Melfi, A.J., Piccirillo, E., Tanner de Oliveira, M.A. F. 1999, Mafic dikes of Salvador (State of Bahia, Brazil): geological and petrological characteristics. Boletim IG-USP, Universidade de São Paulo, Série Científica, 20, 9-14.

Mori, P.E., Reeves, S., Correia, C.T., Haukka, M., 1999, Development of a fused glass disc XRF facility and comparison with the pressed powder pellet technique at Instituto de Geociências, University of São Paulo: Revista Brasileira de Geociências, v. 29, pp. 441-446.

Navarro, M.S., Andrade, S., Ulbrich, H.H.G.J., Gomes, C.B., Girardi, V.A.V., 2008, The analysis of rare earth elements with ICP-MS in basaltic and related rocks: testing the efficiency of sample decomposition procedures: Geostandards and Geoanalytical Research, v. 32(2), pp. 167-180.

Payolla, B.L., Bettencourt, J.S., Kozuch, M., Leite Jr., W.B., Fetter, A.H., and Van Schmus, W.R., 2002, Geological evolution of the basement rocks in the east-central part of the Rondonia Tin Province, SW Amazonian Craton, Brazil: U-Pb and SmNd isotopic constraints: Precambrian Research, v. 119, pp. 141-169.

Pearce, T.H., 1968, A contribution to the theory of variations diagrams: Contributions Mineralogy and Petrology, v. 19, pp. 42-57. 
Rivalenti, G., Mazzucchelli, M., Girardi, V.A.V., Cavazzini, G., Finatti, C., Barbieri, M.A., Teixeira, W., 1998, Petrogenesis of the Paleoproterozoic basalt-andesiterhyolitedyke association in the Carajas region, Amazonian craton: Lithos, v. 43, pp. 235-265.

Rizzotto, G.J., 1999, Petrologia e ambiente tectônico do Grupo Nova Brasilândia, RO: MSc Thesis, Institutode Geociências, Universidade Federal do Rio Grande do Sul, $137 \mathrm{p}$.

Rizzotto, G.J., Scandolara, J.E., Silva, C.R., Dall'Agnol, R., and Morais, P.R., 1995, Geology and preliminary geochemistry of the middle proterozoic Serra da Providência rapakivi granite - Rondônia, Brazil. In: Dall'Agnol, R., Macambira, M.J.B., Costi, H.T., eds, Symposium on Rapakivi Granites and related rocks: Belém, Abstracts Volume. Belém, Brazil, pp. 67-68.

Rizzotto, G.J.; Lima, E.F., and Chemale Junior, F., 2001, Geologia do Grupo Nova Brasilândia, sudeste de Rondônia, acresção continental e implicações geotectônicas. In: Reis, N.J., and Monteiro, M.A.S., coords, Contribuições à Geologia da Amazônia: SBG, v. 2, pp. 342-442.

Rizzotto, G.J., Bettencourt, J.S., Teixeira, W., D'Agrella Filho, M.S., Vasconcelos, P. Basei, M.A.S., Onoe, A., and Passarelli, C.R., 2002, Geologia e Geocronologia da Suíte Metamórfica Colorado e suas encaixantes, SE de Rondônia; implicações para a evolução mesoproterozóica do Craton Amazônico: Geologia USP, Série Científica, v. 2, pp. 41-56.

Rizzotto, G.J., Quadros, L.Q., 2007, Margem Passiva e granitos Orogênicos do Ectasiano em Rondônia: X Simpósio de Geologia da Amazônia, Porto Velho, CDROM, 2007.

Rollinson, H., 1993, Using geochemical data: evaluation, presentation, interpretation: Pearson Education Limited, Longman Group, UK

Sadowski, G.R., Bettencourt, J.S., 1996, Mesoproterozoic tectonic correlations between eastern Laurentia and the western border of the Amazonian Craton: Precambrian Research, v. 76, pp. 213-227.

Saes, G.S., 1999, Evolução tectônica e paleogeográfica do aulacógeno Aguapeí (1.2-1.0 Ga) e dos terrenos do seu embasamento na porção sul do Cráton Amazônico: Tese de Doutoramento, Instituto de Geociências, Universidade de São Paulo, 135 p.

Santos, J.O.S., 2003, Geotectônica dos Escudos das Guianas e Brasil Central. In: Bizzi, L.A., Schobbenhaus, C., Vidotti, R.M., and Gonçalves, J.H., orgs, Geologia, Tectônica e Recursos Minerais do Brasil: CPRM, Brasília, Chapter IV (II), pp 169-226.

Santos, J.O.S., Hartmann, L.A., Gaudette, H.E., Groves, D.I., McNaughton, N.J., and Fletcher, I.R., 2000, A new understanding of the provinces of Amazon craton based on integration of field mapping and $\mathrm{U}-\mathrm{Pb}$ and $\mathrm{Sm}-\mathrm{Nd}$ geochronology. Gondwana Research, v. 3, pp. 489-506.

Santos, J.O.S., Rizzotto, G.J., Chemale Junior, F., Hartmann, L.A., Quadros, M.L.E.S \& McNaughton, N.J. 2003. Three distinctive collisional orogenies in the southwestern Amazon craton: constraints from U-Pb geochronology. In: IV South American Symposium on Isotope Geology, short papers. Salvador, Brazil, v.1, p.282-285

Sato, K., Tassinari, C.C.G., Kawashita, K., and Petronilho, L., 1995, O Método Geocronológico Sm-Nd no IG/USP e suas aplicações: Annals, Brazilian Academy of Sciences, v. 67(3), pp. 313-336.

Sun, S.S., and McDonough, W.F., 1989, Chemical and isotopic systematics of oceanic basalts: implications for mantle composition and process. In: Saunders, A.D. Norry, M.J., eds, Magmatism in the Ocean Basins: Geological Society, Special Publications, v. 42, pp. 313-345.

Takahashi, E., Nakajima, K., Wright, T.L., 1998, Origin of the Columbia River basalts: melting model of a heterogeneous plume head: Earth and Planetary Science Letters, v. 162 , pp. $63-80$

Tassinari, C.C.G., Bettencourt, J.S., Geraldes, M.C., Macambira, M.J.B., and Lafon, J.M., 2000, The Amazon Craton. In: Cordani, U.G., Miliani, E.J., Thomaz-Filho, A., Campos, D.A., eds, Tectonic evolution of South America. In: 31st International Geological Congress, Rio de Janeiro, Brazil, pp. 41-95.

Tassinari, C.C.G., and Macambira, M.J.B., 2004, A evolução tectônica do Cráton Amazônico. In: Mantesso Neto et al, eds, Geologia do Continente Sul-Americano: A evolução da obra de Fernando F. M. de Almeida: São Paulo, Editora Beca, pp. 471-475.

Teixeira, W., Bettencourt, J.S., Girardi, V.A.V., Onoe, A., Sato, K., 2006, Mesoproterozoic mantle heterogeneity in the SW Amazonian Craton: ${ }^{40} \mathrm{Ar} /{ }^{39} \mathrm{Ar}$ and $\mathrm{Sr}-\mathrm{Nd}$ isotopic evidence from mafic-felsic rocks. Dyke Swarms: Time Markers of Crustal Evolution: Hanski, Mertanen, Ramo, Vuollo, eds, Balkema Editor, Finland, pp. 113-129.

Teixeira, W., Tassinari, C.C.G., Cordani, U.G., and Kawashita, K., 1989, A review of the geochronology of the Amazonian Craton: tectonic implications: Precambrian Research, v. 42, pp. 213-27.

Tohver, E., van der Pluijm, B.A., Mezger, K., Essene, E., Scandorala, J.E., and Rizzotto, G.J., 2004, Significance of the Nova Brasilândia metasedimentary belt in western Brazil: Redefining the Mesoproterozoic boundary of the Amazon Craton: Tectonics, TC6004 doi: 10.1029/2003 TC001563.

Tohver, E., van der Pluijm, B.A., Scandolara, J.E., and Essene, E.J., 2005b, Grenvilleaged deformation of Amazônia (Rondônia, Brazil): evidence for collision with southern Laurentia: Journal Geology, v. 113, pp. 309-323.

Tohver, E., Teixeira, W., van der Pluijm, B.A., Geraldes, M.C., Bettencourt, J.S., Riz zotto, G., 2006, A geochronological transect across the restored Grenville orogen of Laurentia and Amazonia, with implications for crustal architecture: Geology, v. 34 , pp. 669-672.
Vasconcelos, P.M.P., Onoe, A.T., Kawashita, K., Soares, A.J., and Teixeira, W., 2002 ${ }^{40} \mathrm{Ar} /{ }^{39} \mathrm{Ar}$ geochronology at the Instituto de Geociências, USP: instrumentation, analytical procedures, and calibration: Annals, Brazilian Academy of Sciences, v. 74, pp. 297-342.

Weaver, B.L., 1991, The origin of ocean island basalt end-member compositions: trace element and isotopic constraints: Earth and Planetary Science Letters, v. 104, pp. 381-397.

Zindler, A., and Hart, S., 1986, Chemical geodynamics: Annual Review Earth and Planetary Science Letters, v. 14, pp. 493-571.

Vicente A. V. Girardi is full Professor of petrology at the Institute of Geoscience of the University of São Paulo, and has been Director of the same Institute. Member of the Brazilian Academy of Sciences and of the Academy of Science of São Paulo State. Scientic Researcher of the Brazilian National Research Council, CNPq. His research activities are mainly concerned with the study of mafic and ultramafic rocks and associated mineralizations of the South American Platform.

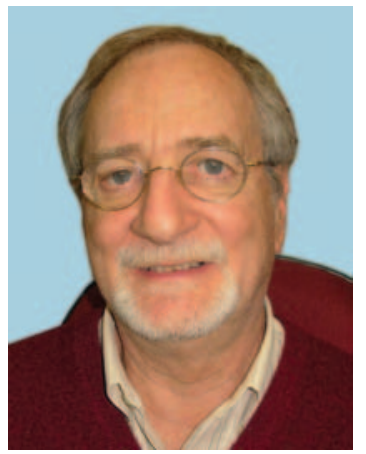

Wilson Teixeira is full Professor of the Dept. of Mineralogy and Geotectonics of the $I G c / U S P$, Brazil and staff-member of the Geochronological Research Center of the Institute. Member of the Brazilian Academy of Sciences and of the Academy of Sciences of São Paulo State. He has been Director of IGc/USP and Director of Estação Ciência, USP, and has been distinguished as "Comendador" of the National Order of Scientific Merit of Brazil. Researcher 1A of the Brazilian National Research Council. He got the Jabuti Award from the Brazilian Chamber of Publishers. Co-leader of the Brazilian Working Group for IGCP-257, and leader for IGCP-204. Research activities: Precambrian Geology of the Amazonian and São Francisco cratons; Geochronology and Isotopic Geo-chemistry; Science Education and Popularization.

Jorge Silva Bettencourt is, since 2000, a research Professor at IGc/USP after a long career at USP and in mining industry. His research activity is in the fields of crustal evolution, metallogeny and mineral exploration. Most of the research has been directed toward rapakivi and rare-metal granites and granitoid-related base and precious metal deposits with major projects in the Amazonian Craton, Brazil. He was leader of the IGCP-426. In 2002 he received the "Barlow Memorial Medal" from the Canadian Institute of Mining, Metallurgy and Petroleum (CIM), and in 2004 the "José Bonifácio de Andrade e Silva Medal" from the Brazilian Geological Society.
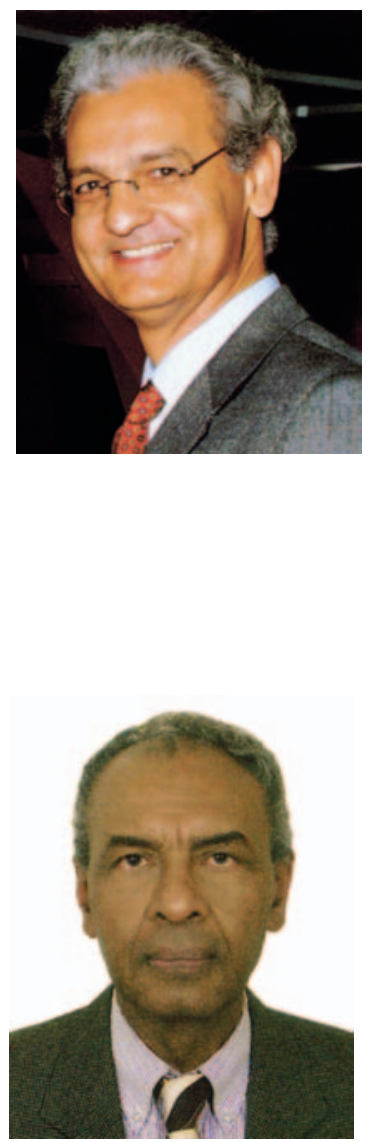